\title{
Serum Response Factor Promotes Resilience to Chronic Social Stress through the Induction of $\Delta$ FosB
}

\author{
Vincent Vialou, ${ }^{1 \star}$ Ian Maze, ${ }^{1 \star}$ William Renthal, ${ }^{2}$ Quincey C. LaPlant, ${ }^{1}$ Emily L. Watts, ${ }^{1}$ Ezekiell Mouzon, ${ }^{1}$ \\ Subroto Ghose, ${ }^{2}$ Carol A. Tamminga, ${ }^{2}$ and Eric J. Nestler ${ }^{1}$ \\ ${ }^{1}$ Fishberg Department of Neuroscience, Mount Sinai School of Medicine, New York, New York 10029, and 2Department of Psychiatry, University of Texas \\ Southwestern Medical Center, Dallas, Texas 75390
}

The molecular mechanisms underlying stress- and drug-induced neuronal adaptations are incompletely understood. One molecule implicated in such adaptations is $\triangle \mathrm{FosB}$, a transcription factor that accumulates in the rodent nucleus accumbens (NAc), a key brain reward region, in response to either chronic stress or repeated exposure to drugs of abuse. The upstream transcriptional mechanisms controlling $\Delta$ FosB induction by these environmental stimuli remain elusive. Here, we identify the activity-dependent transcription factor, serum response factor (SRF), as a novel upstream mediator of stress-, but not cocaine-, induced $\triangle F$ FosB. SRF is downregulated in NAc of both depressed human patients and in mice chronically exposed to social defeat stress. This downregulation of SRF is absent in resilient animals. Through the use of inducible mutagenesis, we show that stress-mediated induction of $\Delta$ FosB, which occurs predominantly in resilient mice, is dependent on SRF expression in this brain region. Furthermore, NAc-specific genetic deletion of SRF promotes a variety of prodepressant- and proanxiety-like phenotypes and renders animals more sensitive to the deleterious effects of chronic stress. In contrast, we demonstrate that SRF does not play a role in $\triangle \mathrm{FosB}$ accumulation in NAc in response to chronic cocaine exposure. Furthermore, NAc-specific knock-out of SRF has no effect on cocaine-induced behaviors, indicating that chronic social defeat stress and repeated cocaine exposure regulate $\Delta$ FosB accumulation and behavioral sensitivity through independent mechanisms.

\section{Introduction}

The nucleus accumbens (NAc), a key brain reward region, is important for integrating sensory and cognitive inputs that drive motivationally relevant behaviors in response to environmental stimuli (Nestler and Carlezon, 2006; Sesack and Grace, 2010). The NAc also has been implicated in behavioral abnormalities associated with drug addiction and depression. Accordingly, targeting the NAc with deep brain stimulation has been shown to alleviate depression- and addiction-like behaviors in both humans and rodents (Schlaepfer et al., 2008; Vassoler et al., 2008; Heinze et al., 2009; Kuhn et al., 2009).

Repeated exposure to drugs of abuse or stress induces altered patterns of gene expression in NAc, potentially underlying the chronicity of addiction and depression (Berton et al., 2006; Krishnan et al., 2007; Maze et al., 2010; Vialou et al., 2010). Interestingly, the transcription factor $\Delta \mathrm{FosB}$, a splice product of the fos $B$ gene, accumulates in NAc in response to repeated drug or stress exposure (Nestler, 2008; Perrotti et al., 2008; Vialou et al., 2010). $\Delta$ FosB has been proposed as a potential molecular switch guiding the transition from recreational drug use to the chronically addicted state (Nestler et al., 1999; McClung et al., 2004;

Received May 16, 2010; revised Aug. 20, 2010; accepted Sept. 14, 2010.

This work was supported by grants from the National Institute of Mental Health and National Institute on Drug Abuse and by a research alliance with AstraZeneca. We thank David D. Ginty for providing the Srffl/fl mice.

${ }^{*}$ V.V. and I.M. contributed equally to this work.

Correspondence should be addressed to Eric J. Nestler, Fishberg Department of Neuroscience, Mount Sinai School of Medicine, One Gustave L. Levy Place, Box 1065, New York, NY 10029-6574. E-mail: eric.nestler@mssm.edu. DOI:10.1523/JNEUROSCI.2496-10.2010

Copyright $\odot 2010$ the authors $\quad 0270-6474 / 10 / 3014585-08 \$ 15.00 / 0$
Renthal et al., 2009), as its accumulation in NAc enhances rewarding responses to several drugs of abuse. More recently, the role of $\Delta$ FosB induction in NAc following chronic social defeat stress (Nikulina et al., 2008; Vialou et al., 2010) has been elucidated: $\Delta$ FosB promotes active coping responses to stressful stimuli and increases resilience. Although $\Delta$ FosB induction occurs in a stimulus-dependent manner, the mechanisms responsible for drug- and stress-induced $\Delta$ FosB accumulation in NAc remain unknown.

Serum response factor (SRF) is a transcription factor required for the activity-dependent transcriptional activation of several immediate early genes, including $c$-fos, fosb, Egrl, and Arc (Knöll and Nordheim, 2009). Recent studies have demonstrated SRF's effects on the morphological and cytoarchitectural properties of neurons, including regulation of synaptic activity and circuitry formation in the adult brain (Knöll and Nordheim, 2009). These findings prompted us to investigate whether SRF is functionally regulated by chronic exposure to drugs of abuse or stress, as well as the potential impact of such regulation on $\Delta$ FosB induction under these conditions.

Here, we describe a novel mechanism through which downregulation of SRF in NAc promotes prodepressant and anxiogenic phenotypes, ultimately increasing an animal's vulnerability to the deleterious effects of chronic stress. These effects are mediated, in part, by the loss of $\Delta$ FosB induction in NAc of stressed animals. Observed decreases in SRF and $\Delta$ FosB expression in postmortem NAc tissue obtained from depressed patients support the relevance of our findings to human depression. Interestingly, this mechanism controlling $\Delta$ FosB accumulation appears 
to be stress-specific: chronic cocaine exposure has no effect on SRF expression, SRF deletion from the NAc has no impact on $\Delta$ FosB accumulation following chronic cocaine exposure, and such SRF deletion has no effect on cocaine-induced behaviors. This novel interplay between SRF and $\Delta$ FosB, in the context of stress, may represent an important homeostatic mechanism regulating an individual's sensitivity to chronic stress.

\section{Materials and Methods}

Animals

Eight-week-old C57BL/6J male mice (Jackson Laboratory) were used in all behavioral and biochemical experiments. All animals were habituated to the animal facility for at least 1 week before experimental manipulations and were maintained at $23-25^{\circ} \mathrm{C}$ on a $12 \mathrm{~h}$ light/dark cycle (lights on from 7:00 A.M. to 7:00 P.M.) with ad libitum access to food and water. Experiments were conducted in accordance with guidelines of the Society for Neuroscience and the institutional animal care and use committee at Mount Sinai School of Medicine.

For cocaine experiments [Western blotting and quantitative chromatin immunoprecipitation (ChIP)], 8- to 10-week-old male C57BL/6J mice were used. Animals received seven daily intraperitoneal injections of either saline or cocaine ( $20 \mathrm{mg} / \mathrm{kg}$ cocaine-HCl; Sigma). Mice were used $24 \mathrm{~h}$ after the final treatment. For behavioral experiments, mice were singly housed postsurgery and were treated with $10 \mathrm{mg} / \mathrm{kg}$ (locomotor sensitization) or $7.5 \mathrm{mg} / \mathrm{kg}$ (conditioned place preference) cocaine- $\mathrm{HCl}$ intraperitoneally, as described below.

$S r f^{\mathrm{fl} / \mathrm{fl}}$ mice were generated as previously described (Ramanan et al., 2005). NAc-specific knock-out of Srf was achieved through stereotaxic injection and subsequent viral overexpression of Cre recombinase (Cre) fused to green fluorescent protein (GFP) using adeno-associated virus $(\mathrm{AAV})$ vectors. A nonself-deleting Cre was used. AAV-GFP was injected in place of AAV-Cre-GFP in $S r f^{\mathrm{f} / \mathrm{fl}}$ mice as a control. Briefly, mice were anesthetized using a mixture of ketamine $(10 \mathrm{mg} / \mathrm{kg})$ and xylazine $(10$ $\mathrm{mg} / \mathrm{kg}$ ), with the following stereotaxic coordinates used for viral delivery: +1.6 (anterior/posterior), + 1.5 (lateral), -4.4 (dorsal/ventral) at an angle of $10^{\circ}$ from the midline (relative to bregma). A total of $0.5 \mu \mathrm{l}$ of purified virus was delivered bilaterally over a $5 \mathrm{~min}$ period $(0.1 \mu \mathrm{l} / \mathrm{min})$, followed by $5 \mathrm{~min}$ of rest. Mice were tested 2 weeks after surgery, when viral expression was maximal, and viral injection sites were confirmed for all animals using standard histological methods. Efficiency of viralmediated Cre expression was validated by immunohistochemistry and by reverse-transcriptase PCR for Srf conducted on microdissected NAc punches from animals given AAV-Cre-GFP and AAV-GFP into the NAc. AAV-GFP and AAV-Cre-GFP viruses were generated as previously described (Maze et al., 2010).

\section{Behavioral procedures}

Social defeat stress. C57BL/6J mice were subjected to chronic social defeat stress for 10 consecutive days as described previously (Berton et al., 2006; Krishnan et al., 2007; Vialou et al., 2010). Briefly, each mouse was exposed to an unfamiliar and aggressive male CD1 retired breeder mouse for 5 min per day. Following direct interaction with the CD1 aggressor, animals were then placed in an adjacent compartment of the same cage for the next $24 \mathrm{~h}$ with sensory but not physical contact. Control animals were housed in equivalent cages but with members of the same strain. Social interaction tests were performed $24 \mathrm{~h}$ following the final day of defeat.

Social avoidance to an unfamiliar CD1 male mouse was assessed according to published protocols (Berton et al., 2006; Krishnan et al., 2007; Vialou et al., 2010). The experimental mouse was first introduced into an open-field containing an empty wire mesh cage for $2.5 \mathrm{~min}$. During a second session, an unfamiliar CD1 male mouse was introduced into the wired cage. The time spent in the interaction zone (an 8-cm-wide corridor surrounding the cage) was measured. Segregation of defeated mice into susceptible and resilient subpopulations was performed as described previously (Krishnan et al., 2007; Vialou et al., 2010). Since the majority of control mice spent more time interacting with a social target than with an empty target enclosure, an interaction ratio of 100 (equal time spent in the interaction zone in the presence versus absence of a social target) was set as a cutoff. Mice with scores $<100$ were labeled as susceptible, and those with scores $\geq 100$ were labeled as resilient. Extensive behavioral, biochemical, and electrophysiological analyses support the validity of these distinct susceptible and resilient subpopulations (Krishnan et al., 2007; Wilkinson et al., 2009; Vialou et al., 2010).

To examine the vulnerability of $S r f^{\mathrm{fl} / \mathrm{fl}}$ mice to social defeat stress, the mice, injected bilaterally with AAV-GFP or AAV-Cre-GFP, were subjected to three consecutives defeats on the same day and then tested for social interaction $24 \mathrm{~h}$ later. This submaximal defeat procedure has been validated previously to reveal prosusceptibility phenotypes following genetic manipulations (Krishnan et al., 2007; Vialou et al., 2010).

Learned helplessness. Srf ${ }^{\mathrm{fl} / \mathrm{fl}}$ mice overexpressing either AAV-GFP or AAV-Cre-GFP were subjected to the learned helplessness procedure as described previously (Berton et al., 2007). Briefly, mice were exposed to intermittent, inescapable foot shocks for $1 \mathrm{~h}$ over 2 consecutives days ( $0.45 \mathrm{~mA}, 5 \mathrm{~s}$ duration). On the day of the test, mice were reintroduced into the box for 15 consecutive escape trials. During each trial, a continuous shock was delivered and mice were given the opportunity to escape by entering the adjacent, nonelectrified compartment. Following a successful escape, the door was automatically shut and the escape latency was recorded. When mice did not escape within $25 \mathrm{~s}$, the trial was terminated and was recorded as a failure. Prior studies have shown that viral expression in NAc and other regions has no effect on baseline escape behavior in the absence of stress (Newton et al., 2002; Berton et al., 2007).

Locomotor sensitization. Two weeks following intra-NAc injections of either AAV-GFP or AAV-Cre-GFP, $S r f^{\mathrm{f} / \mathrm{fl}}$ mice were subjected to locomotor sensitization. Mice were habituated to the locomotor arena for 30 $\min$ per day for $4 \mathrm{~d}$. Following habituation, animals were injected intraperitoneally with $10 \mathrm{mg} / \mathrm{kg}$ cocaine- $\mathrm{HCl}$ and placed into the locomotor boxes. The animals' locomotor activities were recorded using a photobeam system (San Diego Instruments) as ambulatory beam breaks for 30 min per day. Locomotor sensitization was recorded over a period of $6 \mathrm{~d}$.

Conditioned place preference. The place conditioning procedure was conducted as previously described (Maze et al., 2010), with the following modifications. Briefly, $18 \mathrm{~d}$ after intra-NAc infusions of AAV-GFP or AAV-Cre-GFP in $S r f^{\mathrm{fl} / \mathrm{fl}}$ mice, animals were placed into the conditioning chambers, which consisted of three contextually distinct environments. Mice displaying significant preference for either of the two conditioning chambers were excluded from the study ( $<10 \%$ of all animals). Conditioning groups were further balanced to adjust for any chamber bias that still may exist. On subsequent days, animals were injected with saline and confined to one chamber in the afternoon for $30 \mathrm{~min}$ and then injected with cocaine $(7.5 \mathrm{mg} / \mathrm{kg}$, i.p.) and confined for $30 \mathrm{~min}$ to the other chamber the following day, equaling a total of two rounds of association training per treatment (two saline and two cocaine pairings). On the day of the test, mice were placed back into the apparatus without treatment for $20 \mathrm{~min}$ and tested to evaluate side preference. Locomotor responses to cocaine were assessed via beam breaks in the cocaine-paired chambers to ensure effectiveness of drug treatment. For all groups, baseline locomotion in response to saline was assessed to ensure that locomotion was not affected by viral treatment.

Other behavioral tests. Srf $f^{\mathrm{fl} / \mathrm{fl}}$ mice were tested in open-field, light/dark, and forced-swim tests based on published protocols (Vialou et al., 2010). The activity of mice in the open-field was recorded for $5 \mathrm{~min}$ using a video tracking system (Ethovision) under red-light conditions. For the light/dark test, mice were allowed to freely explore a two-chambered box composed of one large illuminated arena connected to a smaller closed arena. Mice were tested for a period of $5 \mathrm{~min}$ to evaluate the amount of time spent in either enclosure. In the open-field and light/dark tests, time spent in the center and light arena, respectively, was evaluated as an inverse index of anxiety-related responses. A $1 \mathrm{~d}$ forced-swim test was conducted for a period of $5 \mathrm{~min}$. Increased time of immobility during the forced-swim test was interpreted as a prodepressant-like behavior. The $1 \mathrm{~d}$ forced-swim test has been extensively used in mice and has been validated as a measure of predictive validity, in that antidepressant therapies reduce immobility times. 
Table 1. Demographic data for human postmortem study

\begin{tabular}{|c|c|c|c|c|c|c|c|}
\hline & Sex & Age & Race & $\begin{array}{l}\text { PMI } \\
\text { (hours) }\end{array}$ & RIN & $\begin{array}{l}\text { Agonal } \\
\text { score }\end{array}$ & $\begin{array}{l}\text { On ADT } \\
\text { at TOD }\end{array}$ \\
\hline \multicolumn{8}{|c|}{ Controls } \\
\hline C1 & $M$ & 63 & $B$ & 15 & 6.1 & 0 & \\
\hline $\mathrm{C} 2$ & $M$ & 34 & $C$ & 21.5 & 9.7 & 0 & \\
\hline C 3 & $M$ & 48 & $C$ & 17.2 & 8.6 & 0 & \\
\hline C4 & $F$ & 50 & $C$ & 10.5 & 9 & 0 & \\
\hline$C 5$ & $M$ & 51 & $C$ & 17.1 & 9.8 & 0 & \\
\hline C6 & M & 57 & $C$ & 7 & 5.5 & 0 & \\
\hline $\mathrm{C7}$ & M & 77 & $C$ & 13.4 & 8.9 & 1 & \\
\hline C8 & $M$ & 47 & $C$ & 22.3 & 8.6 & 0 & \\
\hline C9 & $M$ & 72 & $C$ & 23 & 6.2 & 0 & \\
\hline $\mathrm{C} 10$ & $M$ & 60 & $C$ & 27 & 8.5 & 0 & \\
\hline \multicolumn{8}{|c|}{ Depressed } \\
\hline D1 & $\mathrm{F}$ & 59 & $C$ & 19.8 & 7.8 & 1 & No \\
\hline D2 & $M$ & 61 & $C$ & 19 & 7.5 & 0 & Yes \\
\hline D3 & $\mathrm{F}$ & 41 & $B$ & 13 & n.a. & 0 & No \\
\hline D4 & $M$ & 65 & $C$ & 20.3 & 5.6 & 0 & Yes \\
\hline D5 & $M$ & 25 & $C$ & 21 & 8.6 & 0 & No \\
\hline D6 & $M$ & 42 & $C$ & 17 & 9.1 & 0 & No \\
\hline D7 & $M$ & 24 & $C$ & 18.3 & 6.9 & 0 & Yes \\
\hline D8 & $M$ & 40 & $C$ & 21 & 7.3 & 0 & Yes \\
\hline D9 & $M$ & 61 & $C$ & 21.5 & 9.1 & 0 & No \\
\hline D10 & $M$ & 50 & $C$ & 20.5 & 9.4 & 0 & No \\
\hline
\end{tabular}

Data for each of the individual patients and control subjects from which postmortem NAc samples were obtained. $M$ Male; F, female; B, Black (African-American); C, Caucasian; PMI, postmortem interval; On ADT at TOD, detectable serum levels of antidepressants at time of death. and processed for immunohistochemical analyses. Validation of $\mathrm{Sr} \mathrm{f}^{\mathrm{fl} / \mathrm{fl}}$ knock-out was performed using a polyclonal antibody directed against SRF (1/2000; Santa Cruz Biotechnology). Cre expression was confirmed via GFP (chicken polyclonal, 1/8000, Aves Labs) expression in dissected brains, as the Cre is fused to GFP. For quantification of $\Delta$ FosB induction after social defeat stress in $S r f^{\text {fl/fl }}$ knock-out mice, $\Delta$ FosB was detected using a rabbit polyclonal antibody raised against the $\mathrm{N}$-terminal region of the protein (1/1000; Santa Cruz Biotechnology). Images were taken with a confocal microscope ( $20 \times$ magnification; Zeiss). The number of GFP-immunopositive cells counted as negative and positive for $\Delta$ FosB immunoreactivity was quantified in multiple images for each animal, with mean values subsequently calculated for each animal. Each animal was considered an individual observation for statistical analysis.

\section{Human postmortem NAc tissue}

Human postmortem brain tissue was obtained from the Dallas Brain Collection, where tissue is collected from the Dallas Medical Examiner's Office and University of Texas (UT) Southwestern's Tissue Transplant Program following consent from the next-of-kin. Tissue was analyzed from both males and females matched for age, postmortem interval, RNA integrity number (RIN), and pH. Specific agonal factors, including coma, hypoxia, pyrexia, seizures, dehydration, hypoglycemia, multiple organ failure, and ingestion of neurotoxic substances at time of death influence RNA integrity in postmortem brain tissues (Tomita et al., 2004). We used an agonal factor scale (AFS) to characterize tissue samples on each of these eight conditions. The absence of an agonal factor was assigned a score of 0 and its presence was scored as 1 to provide a total AFS score between 0 and 8 . Tissue with agonal scores of 0 or 1 reflects good quality samples; the case demographics are given in Table 1. Outstanding tissue quality was confirmed by high RIN values. Cases were subjected to a standard dissection before snap freezing in $-40^{\circ} \mathrm{C}$ isopentane and storage at $-80^{\circ} \mathrm{C}$; further dissection of NAc was performed on frozen tissue. The UT Southwestern institutional review board reviewed and approved the collection of this tissue for research use. A direct informant interview was performed for each depression case at a later date, where information regarding the case's illness was documented; a consensus diagnosis of major depressive disorder was made using DSM-IV criteria by two research psychiatrists. None of the cases included in this study had blood toxicology screens positive for drugs of abuse, alcohol, or prescription drugs other than antidepressants. Despite antidepressant treatment, all subjects were clinically depressed at the time of death. Tissue samples were dispensed in a blinded fashion for analysis.

\section{Western blotting}

Human and mouse NAc specimens were processed as described previously (Maze et al., 2010). Frozen tissue was sonicated in a $5 \mathrm{~mm}$ HEPES lysis buffer containing 1\% SDS with protease (Roche) and phosphatase inhibitors (Sigma). Protein concentrations were determined by the $\mathrm{D}_{\mathrm{c}}$ protein assay (Bio-Rad). Equal amounts of protein samples were subjected to SDS-PAGE and Western blotting. Western blots were probed using an antibody to SRF (1/2000; Santa Cruz Biotechnology) or GAPDH (1/1500; Abcam) and were then scanned and quantified using Odyssey imaging system (Licor).

\section{Immunohistochemistry}

$S r f^{\mathrm{ll} / \mathrm{fl}}$ mice were anesthetized and perfused intracardially with $4 \%$ paraformaldehyde/PBS. Brains were removed and cryoprotected in $30 \%$ sucrose/PBS. Coronal sections $(30 \mu \mathrm{m})$ were cut on a freezing microtome
RNA isolation and quantitative PCR

RNA isolation, quantitative PCR (qPCR), and data analysis were performed as previously described (Maze et al., 2010; Vialou et al., 2010). 


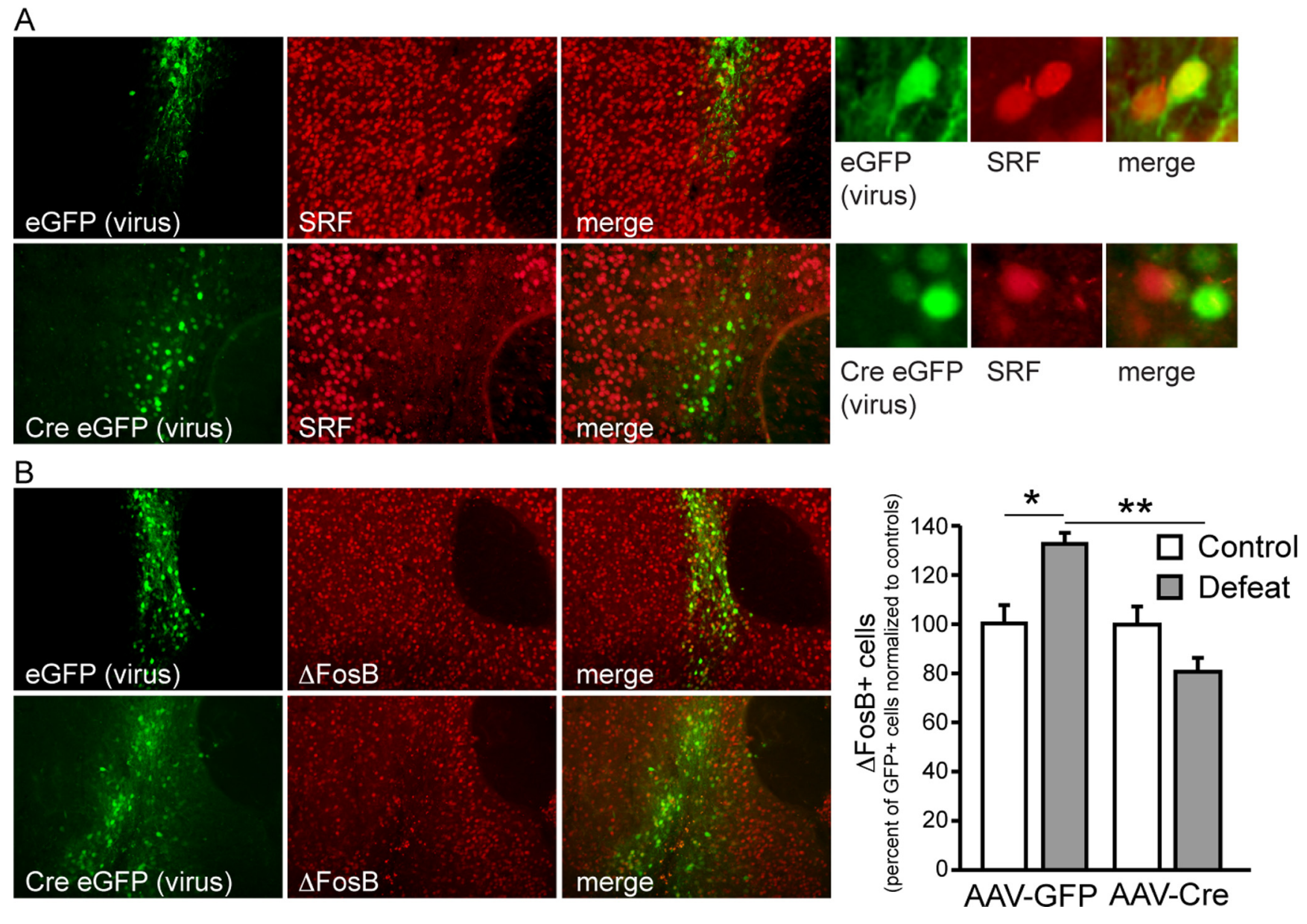

Figure 2. SRF mediates $\triangle$ FosB induction by chronic social defeat stress. A, Injection of AAV-Cre-GFP into the NAc of Srff f//fl mice results in the knock-out of SRF protein in Cre-expressing neurons. Injection of AAV-GFP was without discernable effect. $B$, Such selective knock-out of SRF from the NAc completely blocks the induction of $\triangle$ FosB in NAc following chronic social defeat stress ( $n=$ 4/group). Data displayed are expressed as mean \pm SEM (represented as error bars). ${ }^{*} p<0.05$ versus AAV-GFP control; ${ }^{* *} p<0.01$ versus AAV-GFP defeat.

Briefly, RNA was isolated with TriZol reagent (Invitrogen) and was further purified with RNAeasy micro kits from Qiagen. All RNA samples were determined to have $260 / 280$ and $260 / 230$ values $\geq 1.8$. Reverse transcription was performed using iScript (Bio-Rad). qPCR using SYBR green (Quanta) was performed with an Applied Biosystems 7900HT RT PCR system with the following cycle parameters: 2 min at $95^{\circ} \mathrm{C} ; 40$ cycles of $95^{\circ} \mathrm{C}$ for $15 \mathrm{~s}, 59^{\circ} \mathrm{C}$ for $30 \mathrm{~s}, 72^{\circ} \mathrm{C}$ for $33 \mathrm{~s}$; and graded heating to $95^{\circ} \mathrm{C}$ to generate dissociation curves for confirmation of single PCR products. Data were analyzed by comparing $\mathrm{C}(\mathrm{t})$ values of the treatment condition (control vs susceptible or resilient mice, or human controls vs depressed patients) with the $\Delta \Delta \mathrm{C}(\mathrm{t})$ method (Tsankova et al., 2006). $\Delta$ FosB qPCR primers: foward, AGGCAGAGCTGGAGTCGGAGAT and reverse, GCCGAGGACTTGAACTTCACTCG.

\section{ChIP}

ChIP was performed as previously described (Maze et al., 2010) on pooled bilateral NAc punches from control, susceptible, and resilient mice (four 14-gauge punches/mouse) $1 \mathrm{~h}$ after the last defeat experience and from saline- and cocaine-treated animals $24 \mathrm{~h}$ after the final treatment. Tissue was cross-linked in $1 \%$ formaldehyde. Fixation was subsequently interrupted via glycine application, and tissue was washed and kept at $-80^{\circ} \mathrm{C}$ until use. Sheared chromatin was incubated overnight with an anti-SRF antibody (Santa Cruz Biotechnology) previously bound to magnetic beads (Dynabeads M-280; Invitrogen). After reverse crosslinking and DNA purification, the binding of SRF to the fos $b$ promoter was determined by qPCR using primers spanning a region of the fos $b$ promoter containing two serum response element binding sites. SRF pulldowns were significantly enriched compared with no-antibody con- trols. Mouse fosb gene promoter primers: forward, CCCTCTGACGTAATTGCTAGG and reverse, ACCTCCCAAACTCTCCCTTC.

\section{Statistical analyses}

One-way ANOVAs were used to compare means between control, susceptible, and resilient mice in biochemical and behavioral analyses. Twoway ANOVAs were used to compare $\triangle$ FosB induction by social defeat in Srflocal knock-out mice, as well as to compare the effect of $S r f$ knock-out in the learned helplessness and locomotor sensitization protocols. Student's $t$ tests were used to compare means in the effect of Srf knock-out on $\Delta$ FosB induction, and between groups in human postmortem tissue and mouse ChIP analysis. Differences between experimental conditions were considered statistically significant when $p \leq 0.05$.

\section{Results}

SRF and $\Delta F$ Fos $B$ expression in human depression and socially defeated mice

To explore a potential role for SRF in the development of depressive-like behaviors, we first evaluated SRF protein expression in NAc of postmortem depressed human patients. Depressed subjects displayed significantly reduced SRF levels in NAc compared with their age-matched controls $\left(t_{(19)}=1.9 ; p<0.05\right)$ (Fig. 1A). Given SRF's role in regulating activity-dependent immediate early gene expression (Ramanan et al., 2005), we hypothesized that SRF may be involved in controlling $\Delta$ FosB expression in this brain region. In support of this hypothesis, we observed 
A

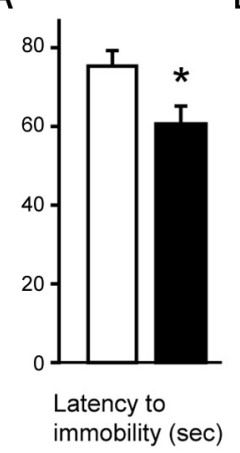

B
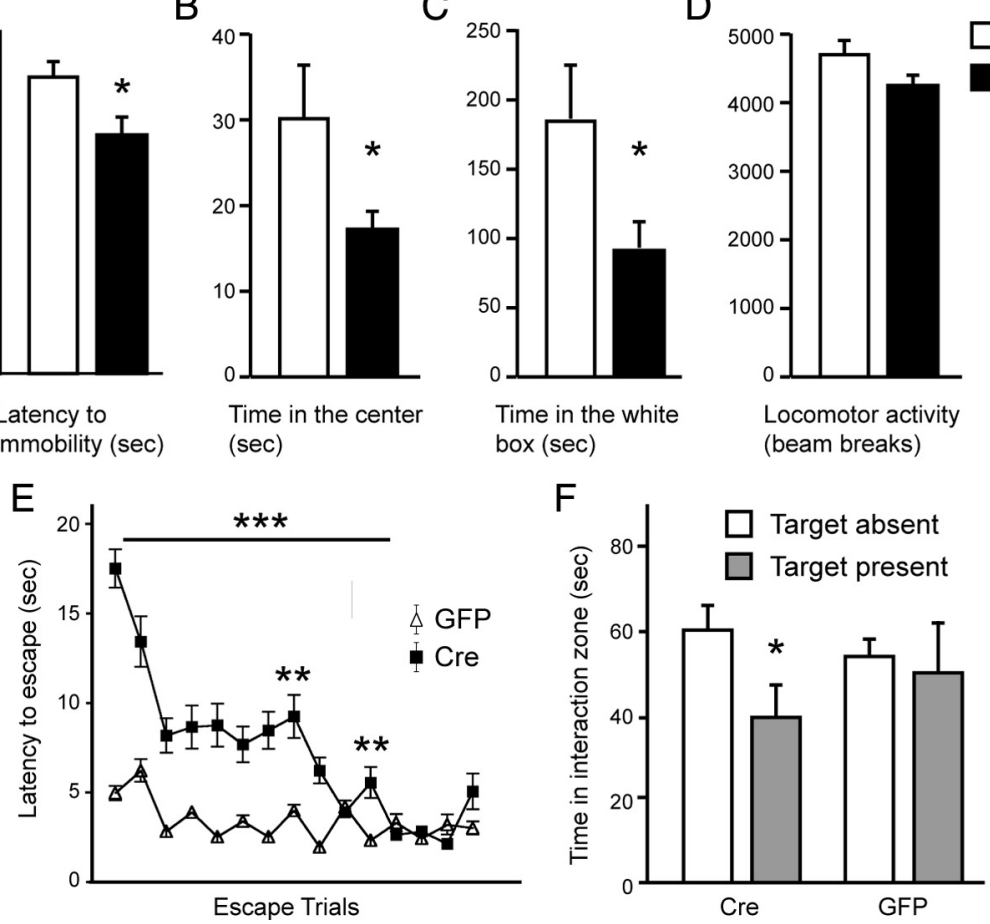

Figure 3. SRF knock-out from the NAc promotes prodepression- and proanxiety-like phenotypes. $\boldsymbol{A}$ - $\boldsymbol{C}$, Selective knock-out of SRF from the NAC, achieved via AAV-Cre-GFP injection into the NAc of Srf $\mathrm{fl}^{\mathrm{l} / \mathrm{fl}}$ mice, reduces latency to immobility in the forced-swim test ( $n=14-18$ /group; $\boldsymbol{A})$ and reduces time spent in the center and time spent in the light compartment in the open-field $(\boldsymbol{B})$ and light/dark ( $\boldsymbol{C}$ tests, respectively ( $n=5-15 /$ group). $\boldsymbol{D}$, No difference in basal locomotor activity was observed in the open-field of mice that received intra-NAc injections of AAV-GFP or AAV-Cre-GFP. $\boldsymbol{E}, \boldsymbol{F}$, Increased susceptibility to learned helplessness ( $n=$ 7-8/group; $\boldsymbol{E}$ ) and social defeat stress ( $n=5-6 /$ group; $\boldsymbol{F}$ ), as measured, respectively, by the latency to escape and social interaction time. Data displayed are expressed as mean \pm SEM (represented as error bars). ${ }^{*} p<0.05$ versus GFP or versus target absent; ${ }^{* *} p<0.01$ versus GFP; ${ }^{* * *} p<0.001$ versus GFP.

that $\Delta f o s b$ mRNA levels were also significantly reduced in NAc of depressed humans $\left(t_{(16)}=1.8 ; p<0.05\right)$ (Fig. $1 B$ ). This is consistent with recent findings of decreased levels of $\Delta$ FosB protein under these conditions as well (Vialou et al., 2010).

To extend these findings, we used the chronic social defeat stress protocol in mice. Two distinguishable groups of defeated mice, susceptible and resilient, were apparent (Krishnan et al., 2007) based on a measure of social avoidance, in which susceptible animals displayed significantly reduced social interaction compared with both control and resilient animals $\left(F_{(2,23)}=\right.$ $157.2 ; p<0.001 ; t$ tests with a Bonferroni correction, susceptible vs control, $p<0.001$; resilient vs control, $p<0.05$; resilient vs susceptible, $p<0.01$ ) (Fig. $1 C$ ). Two days after the last defeat episode, susceptible, resilient, and nondefeated control mice were analyzed for SRF expression in NAc. Similar to findings in human depression, SRF protein levels were significantly reduced in NAc of susceptible mice compared with controls, whereas SRF levels were unaffected in NAc of resilient mice $\left(F_{(2,32)}=4.7 ; p<\right.$ 0.05 ; $t$ tests with a Bonferroni correction, susceptible vs control, $p<0.05$; resilient vs susceptible, $p<0.05$ ) (Fig. $1 D$ ).

Next, we examined $\Delta$ fos $b$ mRNA expression in NAc of these three groups of animals and observed a significant increase in $\Delta f o s b$ expression in resilient animals only, with a trend but no significant increase observed in susceptible mice $\left(t_{(14)}=2.1 ; p<\right.$ 0.05 ) (Fig. $1 E$ ). To further investigate possible interactions between SRF levels and $\Delta$ fos $b$ transcription, we used ChIP to examine whether SRF binding to the fosb gene promoter was altered after chronic social defeat stress in separate cohorts of susceptible and resilient mice. Resilient animals displayed significantly en- hanced SRF binding to the fosb promoter in NAc compared with controls $\left(t_{(8)}=\right.$ $2.1 ; p<0.05)$ as well as compared with susceptible mice $\left(t_{(8)}=2.0 ; p<0.05\right)$. No difference was observed between controls and susceptible mice, probably reflecting the lack of SRF induction in susceptible mice (Fig. $1 F$ ).

To confirm SRF's role in the regulation of $\Delta$ FosB following chronic social defeat stress, $S r f^{\mathrm{fl} / \mathrm{fl}}$ mice were used to examine the effect of a selective deletion of SRF from the NAc on stress induction of $\Delta$ FosB. $S r f^{\mathrm{fl} / \mathrm{fl}}$ mice were stereotaxically injected intra-NAc with AAV vectors expressing GFP or Cre-GFP. An NAcspecific knock-out of SRF induced by AAV-Cre-GFP was confirmed immunohistochemically (Fig. 2A). Indeed, there was no overlap between SRF staining and Cre expression, demonstrating the effectiveness of the knock-out. In microdissected NAc punches, we detected a significant $50 \%$ decrease in SRF protein levels $\left(t_{(11)}=4.3 ; p<0.001\right)$. The magnitude likely reflects the fact that a fraction of tissue in such microdissections is not virally infected.

We next performed quantitative immunohistochemistry for $\Delta$ FosB in NAc of defeated $S r f^{\mathrm{fl} / \mathrm{fl}}$ mice injected intra-NAc with either AAV-Cre-GFP or AAV-GFP. Following chronic social defeat stress, $\Delta$ FosB expression was significantly induced in NAc of AAV-GFP-injected animals (virus $\times$ treatment interaction, $F_{(1,12)}=6.4 ; t$ tests with a Bonferroni correction, control vs defeat, $p<0.05$; AAV-Cre vs AAV-GFP, $p<0.01$ ). However, this induction was not observed in $S r f^{\mathrm{fl} / \mathrm{fl}}$ mice receiving AAV-Cre-GFP (Fig. $2 \mathrm{~B}$ ), demonstrating that $\Delta$ FosB induction in NAc by chronic stress requires SRF.

\section{SRF knock-out in NAc promotes prodepression- and proanxiety-like phenotypes}

Since $\Delta$ FosB induction by chronic social defeat stress has previously been shown to mediate resilience (Vialou et al., 2010), we hypothesized that downregulation of SRF, and the resulting loss of $\Delta$ FosB induction, in susceptible animals may represent a negative adaptation that ultimately renders animals more vulnerable to the deleterious effects of stress. To test this hypothesis, we induced a local NAc-specific deletion of the Srf gene in adult $S r f^{\mathrm{fl} / \mathrm{fl}}$ mice as described above, and the resulting mice and their controls were tested in a battery of behavioral paradigms to assess baseline depression- and anxiety-like behavior. Local NAc deletion of SRF promoted a prodepression-like effect as measured via the forced-swim test $\left(t_{(30)}=2.5 ; p<0.05\right)$, as well as an anxiogenic effect as measured in the open-field $\left(t_{(38)}=1.9 ; p<0.05\right)$ and light/dark tests $\left(t_{(8)}=1.9 ; p<0.05\right)$. Thus, $S r f^{\mathrm{fl} / \mathrm{fl}}$ mice receiving AAV-Cre-GFP into the NAc exhibited decreased latency to immobility in the forced-swim test, less time in the center of an open field, and less time in the light compartment of a light/dark box compared with AAV-GFP-injected animals (Fig. 3A-C). However, intra-NAc deletion of SRF did not alter baseline levels of locomotion, suggesting that the observed behavioral effects in 
SRF knock-out animals were not due to abnormalities in general locomotor activity (Fig. 3D). These data are interesting in light of previous reports suggesting that, although $\Delta$ FosB in NAc regulates depressive-like behaviors, it does not appear to be involved in anxiety-related responses (Vialou et al., 2010). Our current findings that loss of SRF induces anxiogenic responses suggest that it does so through targets other than $\Delta$ FosB.

We next studied whether SRF deletion in NAc also increases an animal's vulnerability to the detrimental effects of repeated stress. $S r f^{\mathrm{fl} / \mathrm{fl}}$ mice, injected with either AAV-Cre-GFP or AAV-GFP into the NAc, were examined in two depression models, learned helplessness and chronic social defeat stress. In learned helplessness, $S r f^{\mathrm{fl} / \mathrm{fl}}$ animals receiving AAV-Cre-GFP displayed increased latency to escape a foot shock following prior exposure to inescapable foot shock stress (treatment $\times$ trials interaction, $F_{(14,180)}=10.2 ; t$ tests with a Bonferroni correction, $p<0.001$; AAV-Cre vs AAVGFP, $p<0.01$ ), indicating increased susceptibility to stress-induced behavioral deficits (Fig. 3E). Similarly, local SRF deletion from NAc also increased social aversion $\left(t_{(10)}=1.8 ; p<0.05\right)$ compared with AAV-GFP-injected control animals following chronic social defeat stress (Fig. $3 F$ ), a prodepression-like effect.

\section{Lack of involvement of SRF in $\Delta$ FosB induction and behavioral responses to cocaine}

Given that $\Delta$ FosB is also induced in NAc in response to drugs of abuse such as cocaine, it was of interest to examine a potential role for SRF in cocaine action. Unlike chronic social defeat stress, repeated cocaine exposure did not alter SRF protein expression in NAc $\left(t_{(14)}=0.8\right.$; $p>0.05$ ) (Fig. $4 A$ ) and had no effect on SRF binding to the fos $B$ gene promoter in this brain region $\left(t_{(4)}=0.7 ; p>0.05\right)$ (Fig. $4 B$ ). This suggests that, contrary to stress, induction of $\Delta$ FosB after chronic cocaine is not mediated through SRF. We tested this directly by examining whether $\Delta$ FosB accumulation after chronic cocaine is altered in $S r f^{\mathrm{fl} / \mathrm{fl}}$ animals receiving AAV-Cre-GFP versus AAVGFP into NAc. We found that SRF deletion had no effect on cocaine-induced $\triangle$ FosB accumulation in this brain region (Fig. 4C).

To follow up on this surprising finding, we investigated whether a selective SRF knock-out from NAc alters behavioral responses to cocaine. Consistent with SRF's lack of regulation of $\Delta$ FosB induction by cocaine, NAc-specific knock-out of SRF had no effect on locomotor activity induced by acute cocaine or locomotor sensitization seen after repeated cocaine exposures (treatment $\times$ time interaction, $F_{(4,80)}=0.3 ; p>0.05$ ) (Fig. $4 D$ ). Likewise, NAc-specific knock-out of SRF had no effect on
B
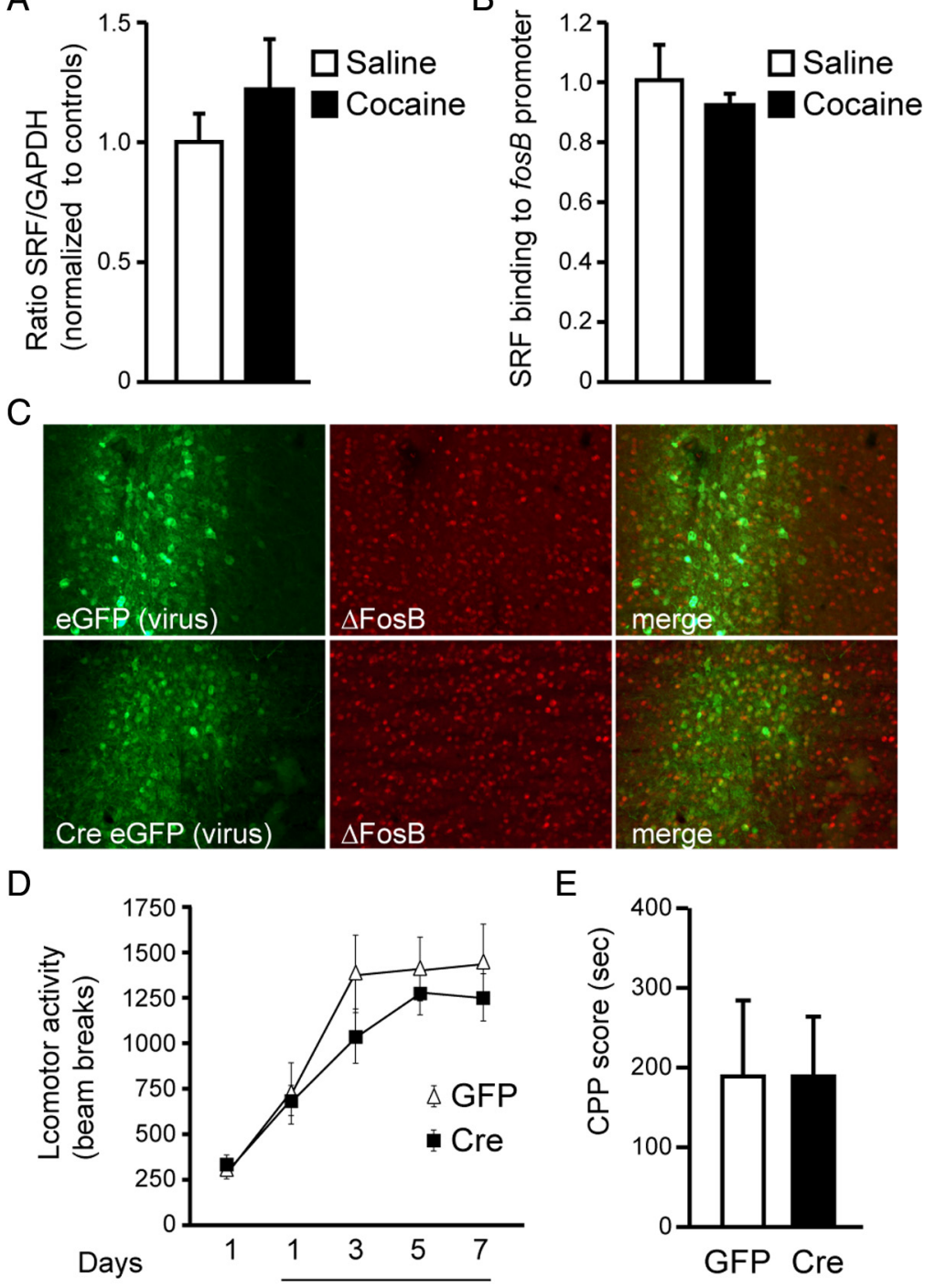

E

Figure 4. Loss of SRF had no effect on cocaine induction of $\Delta$ FosB or cocaine-regulated behaviors. $A, B$, Repeated cocaine exposure $(7 \mathrm{~d}, 20 \mathrm{mg} / \mathrm{kg}$ cocaine- $\mathrm{HCl})$ had no effect on SRF protein expression in NAC $(\boldsymbol{A})$ or on SRF binding to the fos $B$ gene promoter in this brain region $(\boldsymbol{B}) 24 \mathrm{~h}$ after drug exposure ( $n=5 /$ group). $C, \Delta$ FosB accumulation, measured immunocytochemalso had no effect on locomotor activity following a saline injection (d 1) on cocaine-induced locomotor activity and sensitization $n=8 /$ group) (d $1-7 ; \boldsymbol{D})$ or on cocaine conditioned place preference $(n=8 /$ group; $\boldsymbol{E})$. Data displayed are expressed as mean \pm SEM (represented as error bars).

cocaine-conditioned place preference $\left(t_{(14)}=0.1 ; p>0.05\right)$ (Fig. $4 E)$, which provides an indirect measure of cocaine reward.

\section{Discussion}

This study identified SRF as a novel upstream mediator of $\Delta$ FosB in NAc after chronic social defeat stress, and implicates SRF in the development of depressive- and anxiety-like behaviors. We provide direct evidence that chronic social defeat stress decreases SRF levels in NAc of susceptible, but not resilient, animals, and that this downregulation prevents the induction of $\Delta$ FosB in this brain region, which we have shown is necessary for effective coping with chronic stress, i.e., resilience (Vialou et al., 2010). A similar reduction in SRF expression was found in NAc of depressed humans, where $\Delta$ FosB mRNA and protein expression was also reduced. In contrast, $\Delta$ FosB levels were not reduced in the NAc of susceptible mice, despite a downregulation of SRF, 
which implicates other transcriptional mechanisms, as yet unknown, in controlling $\Delta$ FosB expression. A causal role for SRF in mediating $\Delta$ FosB induction in NAc after chronic stress was established by use of inducible genetic deletion of SRF from this brain region. Behavioral analysis of mice with this NAc-specific SRF knock-out further implicates SRF as playing a key role in the development of both baseline and stress-induced depressionand anxiety-like behaviors. In striking contrast, SRF deletion had no effect on $\Delta$ FosB induction in response to chronic cocaine administration or on the behavioral effects of cocaine. These findings support a novel stimulus-specific role for SRF in the regulation of $\Delta$ FosB induction and of behavioral responses to distinct environmental perturbations.

SRF-mediated transcription has previously been shown to respond to synaptic activity, largely triggered by increased calcium influx, as well as to enhanced neurotrophic activity, particularly in the case of brain-derived neurotrophic factor (BDNF) (Bading et al., 1993; Xia et al., 1996; Johnson et al., 1997; Chang et al., 2004; Kalita et al., 2006; Knöll and Nordheim, 2009). This raises the interesting question of why SRF is downregulated in NAc of susceptible, but not resilient, mice after chronic social defeat stress. This differential regulation is likely not mediated by dopamine or BDNF signaling, since susceptible mice display increased BDNF protein levels and increased downstream BDNF signaling in NAc as well as enhanced burst firing of ventral tegmental area (VTA) dopamine neurons, which innervate the NAc, whereas resilient animals display normal levels of BDNF signaling and VTA firing rates (Krishnan et al., 2007). An alternative possibility is that SRF expression is suppressed in NAc in response to altered glutamatergic innervation of this brain region, which we have shown is differentially regulated in susceptible versus resilient mice (Vialou et al., 2010). Further work is needed to directly study this and other possible mechanisms.

Recent studies using genome-wide and other methods suggest that $\sim 5-10 \%$ of SRF target genes in neurons are immediate early genes (Philippar et al., 2004; Ramanan et al., 2005; Etkin et al., 2006; Knöll and Nordheim, 2009). This is consistent with our data demonstrating a critical role for SRF in the induction of $\Delta$ FosB, a truncated product of the fos $b$ immediate early gene, by chronic stress. Interestingly, numerous SRF target genes identified in these various studies also represent known targets of $\Delta$ FosB in NAc (Kumar et al., 2005; Renthal et al., 2008, 2009; Maze et al., 2010). Among these commonly regulated genes are several that are known to regulate the neuronal cytoskeleton (for example, Cdk5, Arc, and Actb). This, in turn, is consistent with reports that SRF influences actin dynamics and neuronal motility in several neuronal cell types (Alberti et al., 2005; Ramanan et al., 2005; Knöll et al., 2006), whereas $\Delta$ FosB is known to affect dendritic spine outgrowth of NAc neurons (Maze et al., 2010). Such common functional endpoints may reflect the concerted effects of SRF, combined with its induction of $\Delta \mathrm{FosB}$, acting on a series of common target genes to influence neuronal morphology and, ultimately, complex behavior.

SRF has also been demonstrated to play critical roles in the regulation of synaptic plasticity and neuronal activity-dependent gene expression and behavior. For example, loss of SRFdependent induction of immediate early genes in response to either voluntary exploration of a novel environment or neuronal activation by electroconvulsive seizures has been associated with impaired long-term synaptic potentiation in the hippocampus of Srf mutants (Ramanan et al., 2005; Etkin et al., 2006). Furthermore, SRF depletion in hippocampus has been shown to cause deficits in long-term synaptic depression, immediate early gene expression induced by a novel context, and impaired habituation during exploration of a novel environment (Etkin et al., 2006). These data establish the importance of SRF in an animal's ability to adapt appropriately to environmental perturbations, as in the aforementioned case of learning to habituate to a new environment, or, in the case of adapting to negative stressful stimuli, to prevent the promulgation of stress-induced behavioral deficits, as in our present study. Thus, we observe that animals exhibiting deficits in SRF expression, either in response to social defeat stress in susceptible individuals or through direct knockdown of SRF, display increased depressive- and anxiety-like behaviors. Given that depressed human subjects also present with decreased SRF levels in the NAc, it is conceivable that SRF plays a fundamental role in regulating an individual's ability to positively adapt to negative environmental stimuli, in part through regulation of $\Delta$ FosB expression in the NAc.

A surprising finding of the present study is that, although SRF is required for $\triangle \mathrm{FosB}$ accumulation in NAc in response to chronic stress, it is not required for $\Delta$ FosB induction within the same brain region in response to chronic cocaine. Likewise, SRF is not required for normal behavioral responses to the drug. These data show that, despite the fact that $\Delta$ FosB is induced in NAc in response to many types of stimuli (Nestler et al., 1999; Nestler, 2008), there appear to be distinct molecular pathways leading to $\Delta$ FosB induction. One possible explanation for these findings is the partially different cell types that show $\Delta$ FosB accumulation in response to stress versus cocaine. Chronic stress induces $\Delta$ FosB approximately equally within the two major subpopulations of NAc medium spiny neurons, those expressing predominantly $D_{1}$ versus $D_{2}$ dopamine receptors, whereas chronic cocaine induces $\Delta$ FosB predominantly within $\mathrm{D}_{1}+$ neurons (Kelz et al., 1999; Perrotti et al., 2004). Thus, it is possible that SRF-dependent pathways may be important for $\Delta$ FosB induction in $\mathrm{D}_{2}+$ neurons. However, this would not explain the complete loss of $\Delta$ FosB induction in SRF knock-out mice after chronic stress, since the induction occurs in both neuronal subtypes. An alternative explanation is that chronic stress and chronic cocaine impinge upon distinct intracellular signaling cascades, by virtue of their distinct modes of action on NAc neurons, with chronic stress perhaps working through altered glutamatergic transmission, as noted earlier, and chronic cocaine working primarily through $\mathrm{D}_{1}$ receptor signaling (Nestler, 2008). Still another possibility is that $\Delta$ FosB induction by chronic stress versus chronic cocaine is dependent on distinct transcriptional mechanisms that are differentially controlled by distinct neural inputs innervating the NAc from various glutamatergic projection regions, for example, several regions of prefrontal cortex, hippocampus, and amygdala. Much further work is needed to explore these and alternative possibilities.

Together, our findings identify a novel transcriptional mechanism through which $\Delta$ FosB is induced in NAc to mediate proresilience responses to stressful stimuli. This study also provides important new insight into the role played by SRF at the level of the NAc in the regulation of depression- and anxiety-like behaviors. Gaining a better understanding of SRF's transcriptional role in the regulation of such behaviors will aid in the identification of novel gene targets involved in resilience to stress-related disorders, and may facilitate the future development of more effective antidepressant therapies.

\section{References}

Alberti S, Krause SM, Kretz O, Philippar U, Lemberger T, Casanova E, Wiebel FF, Schwarz H, Frotscher M, Schütz G, Nordheim A (2005) Neuronal 
migration in the murine rostral migratory stream requires serum response factor. Proc Natl Acad Sci U S A 102:6148-6153.

Bading H, Ginty DD, Greenberg ME (1993) Regulation of gene expression in hippocampal neurons by distinct calcium signaling pathways. Science 260:181-186.

Berton O, McClung CA, Dileone RJ, Krishnan V, Renthal W, Russo SJ, Graham D, Tsankova NM, Bolanos CA, Rios M, Monteggia LM, Self DW, Nestler EJ (2006b) Essential role of BDNF in the mesolimbic dopamine pathway in social defeat stress. Science 311:864-868.

Berton O, Covington HE 3rd, Ebner K, Tsankova NM, Carle TL, Ulery P, Bhonsle A, Barrot M, Krishnan V, Singewald GM, Singewald N, Birnbaum S, Neve RL, Nestler EJ (2007) Induction of $\Delta$ FosB in the periaqueductal gray by stress promotes active coping responses. Neuron 55:289-300.

Chang SH, Poser S, Xia Z (2004) A novel role for serum response factor in neuronal survival. J Neurosci 24:2277-2285.

Etkin A, Alarcón JM, Weisberg SP, Touzani K, Huang YY, Nordheim A, Kandel ER (2006) A role in learning for SRF: deletion in the adult forebrain disrupts LTD and the formation of an immediate memory of a novel context. Neuron 50:127-143.

Heinze HJ, Heldmann M, Voges J, Hinrichs H, Marco-Pallares J, Hopf JM, Müller UJ, Galazky I, Sturm V, Bogerts B, Münte TF (2009) Counteracting incentive sensitization in severe alcohol dependence using deep brain stimulation of the nucleus accumbens: clinical and basic science aspects. Front Hum Neurosci 3:22.

Johnson CM, Hill CS, Chawla S, Treisman R, Bading H (1997) Calcium controls gene expression via three distinct pathways that can function independently of the Ras/mitogen-activated protein kinases (ERKs) signaling cascade. J Neurosci 17:6189-6202.

Kalita K, Kharebava G, Zheng JJ, Hetman M (2006) Role of megakaryoblastic acute leukemia-1 in ERK1/2-dependent stimulation of serum response factor-driven transcription by BDNF or increased synaptic activity. J Neurosci 26:10020-10032.

Kelz MB, Chen J, Carlezon WA Jr, Whisler K, Gilden L, Beckmann AM, Steffen C, Zhang YJ, Marotti L, Self DW, Tkatch T, Baranauskas G, Surmeier DJ, Neve RL, Duman RS, Picciotto MR, Nestler EJ (1999) Expression of the transcription factor $\triangle \mathrm{FosB}$ in the brain controls sensitivity to cocaine. Nature 401:272-276.

Knöll B, Nordheim A (2009) Functional versatility of transcription factors in the nervous system: the SRF paradigm. Trends Neurosci 32:432-442.

Knöll B, Kretz O, Fiedler C, Alberti S, Schütz G, Frotscher M, Nordheim A (2006) Serum response factor controls neuronal circuit assembly in the hippocampus. Nat Neurosci 9:195-204.

Krishnan V, Han MH, Graham DL, Berton O, Renthal W, Russo SJ, Laplant Q, Graham A, Lutter M, Lagace DC, Ghose S, Reister R, Tannous P, Green TA, Neve RL, Chakravarty S, Kumar A, Eisch AJ, Self DW, Lee FS, et al. (2007) Molecular adaptations underlying susceptibility and resistance to social defeat in brain reward regions. Cell 131:391-404.

Kuhn J, Bauer R, Pohl S, Lenartz D, Huff W, Kim EH, Klosterkoetter J, Sturm $\mathrm{V}$ (2009) Observations on unaided smoking cessation after deep brain stimulation of the nucleus accumbens. Eur Addict Res 15:196-201.

Kumar A, Choi KH, Renthal W, Tsankova NM, Theobald DE, Truong HT, Russo SJ, Laplant Q, Sasaki TS, Whistler KN, Neve RL, Self DW, Nestler EJ (2005) Chromatin remodeling is a key mechanism underlying cocaineinduced plasticity in striatum. Neuron 48:303-314.

Maze I, Covington HE 3rd, Dietz DM, LaPlant Q, Renthal W, Russo SJ, Mechanic M, Mouzon E, Neve RL, Haggarty SJ, Ren Y, Sampath SC, Hurd YL, Greengard P, Tarakhovsky A, Schaefer A, Nestler EJ (2010) Essential role of the histone methyltransferase G9a in cocaine-induced plasticity. Science 327:213-216.

McClung CA, Ulery PG, Perrotti LI, Zachariou V, Berton O, Nestler EJ (2004) DeltaFosB: a molecular switch for long-term adaptation in the brain. Brain Res Mol Brain Res 132:146-154.

Nestler EJ (2008) Transcriptional mechanisms of addiction: role of deltaFosB. Philos Trans R Soc Lond B Biol Sci 363:3245-3255.

Nestler EJ, Carlezon WA Jr (2006) The mesolimbic dopamine reward circuit in depression. Biological Psychiatry 59:1151-1159.
Nestler EJ, Kelz MB, Chen J (1999) $\Delta$ FosB: a molecular mediator of longterm neural and behavioral plasticity. Brain Res 835:10-17.

Newton SS, Thome J, Wallace TL, Shirayama Y, Schlesinger L, Sakai N, Chen J, Neve R, Nestler EJ, Duman RS (2002) Inhibition of cAMP response element-binding protein or dynorphin in the nucleus accumbens produces an antidepressant-like effect. J Neurosci 22:10883-10890.

Nikulina EM, Arrillaga-Romany I, Miczek KA, Hammer RP Jr (2008) Longlasting alteration in mesocorticolimbic structures after repeated social defeat stress in rats: time course of mu-opioid receptor mRNA and FosB/ DeltaFosB immunoreactivity. Eur J Neurosci 27:2272-2284.

Perrotti LI, Hadeishi Y, Ulery PG, Barrot M, Monteggia L, Duman RS, Nestler EJ (2004) Induction of $\Delta$ FosB in reward-related brain structures after chronic stress. J Neurosci 24:10594-10602.

Perrotti LI, Weaver RR, Robison B, Renthal W, Maze I, Yazdani S, Elmore RG, Knapp DJ, Selley DE, Martin BR, Sim-Selley L, Bachtell RK, Self DW, Nestler EJ (2008) Distinct patterns of DeltaFosB induction in brain by drugs of abuse. Synapse 62:358-369.

Philippar U, Schratt G, Dieterich C, Müller JM, Galgóczy P, Engel FB, Keating MT, Gertler F, Schüle R, Vingron M, Nordheim A (2004) The SRF target gene Fhl2 antagonizes RhoA/MAL-dependent activation of SRF. Mol Cell $16: 867-880$.

Ramanan N, Shen Y, Sarsfield S, Lemberger T, Schütz G, Linden DJ, Ginty DD (2005) SRF mediates activity-induced gene expression and synaptic plasticity but not neuronal viability. Nat Neurosci 8:759-767.

Renthal W, Carle TL, Maze I, Covington HE 3rd, Truong HT, Alibhai I, Kumar A, Montgomery RL, Olson EN, Nestler EJ (2008) Delta FosB mediates epigenetic desensitization of the c-fos gene after chronic amphetamine exposure. J Neurosci 28:7344-7349.

Renthal W, Kumar A, Xiao G, Wilkinson M, Covington HE 3rd, Maze I, Sikder D, Robison AJ, LaPlant Q, Dietz DM, Russo SJ, Vialou V, Chakravarty S, Kodadek TJ, Stack A, Kabbaj M, Nestler EJ (2009) Genome-wide analysis of chromatin regulation by cocaine reveals a role for sirtuins. Neuron 62:335-348.

Schlaepfer TE, Cohen MX, Frick C, Kosel M, Brodesser D, Axmacher N, Joe AY, Kreft M, Lenartz D, Sturm V (2008) Deep brain stimulation to reward circuitry alleviates anhedonia in refractory major depression. Neuropsychopharmacology 33:368-377.

Sesack SR, Grace AA (2010) Cortico-basal ganglia reward network: microcircuitry. Neuropsychopharmacology 35:27-47.

Tomita H, Vawter MP, Walsh DM, Evans SJ, Choudary PV, Li J, Overman KM, Atz ME, Myers RM, Jones EG, Watson SJ, Akil H, Bunney WE Jr (2004) Effect of agonal and postmortem factors on gene expression profile: quality control in microarray analyses or postmortem human brain. Biol Psychiatry 55:346-352.

Tsankova NM, Berton O, Renthal W, Kumar A, Neve RL, Nestler EJ (2006) Sustained hippocampal chromatin regulation in a mouse model of depression and antidepressant action. Nat Neurosci 9:519-525.

Vassoler FM, Schmidt HD, Gerard ME, Famous KR, Ciraulo DA, Kornetsky C, Knapp CM, Pierce RC (2008) Deep brain stimulation of the nucleus accumbens shell attenuates cocaine priming-induced reinstatement of drug seeking in rats. J Neurosci 28:8735-8739.

Vialou V, Robison AJ, Laplant QC, Covington HE 3rd, Dietz DM, Ohnishi YN, Mouzon E, Rush AJ 3rd, Watts EL, Wallace DL, Iñiguez SD, Ohnishi YH, Steiner MA, Warren BL, Krishnan V, Bolaños CA, Neve RL, Ghose S, Berton O, Tamminga CA, Nestler EJ (2010) $\triangle$ FosB in brain reward circuits mediates resilience to stress and antidepressant responses. Nat Neurosci 13:745-752.

Wilkinson MB, Xiao G, Kumar A, LaPlant Q, Renthal W, Sikder D, Kodadek TJ, Nestler EJ (2009) Imipramine treatment and resiliency exhibit similar chromatin regulation in a key brain reward region. J Neurosci 29:7820-7832.

Xia Z, Dudek H, Miranti CK, Greenberg ME (1996) Calcium influx via the NMDA receptor induces immediate early gene transcription by a MAP kinase/ERK-dependent mechanism. J Neurosci 16:5425-5436. 